\title{
Hasil Belajar Matematika Siswa Menggunakan Media Gambar Dengan Media Model Padat Pada Materi Geometri
}

\author{
Pupung Syaeful Rohman ${ }^{1 *}$, Lusi Susianti ${ }^{2}$, Mohamad Jamaludin ${ }^{3}$ \\ ${ }^{1}$ Dosen Akademi Minyak dan Gas Balongan, ${ }^{2}$ Guru MTsN 1 Purwakarta, ${ }^{3}$ Kepala SMK \\ Miftahul Huda Ciwaringin \\ ${ }^{1}$ pupungsr@gmail.com, ${ }^{2}$ lusisusianti80@gmail.com, ${ }^{3}$ pawang.jamal@gmail.com
}

\begin{abstract}
Abstrak
Penelitian ini bertujuan untuk menganalisis perbedaan rata-rata hasil belajar matematika siswa pada materi geometri yang pembelajarannya menggunakan media gambar dengan media model padat. Metode penelitian yang digunakan adalah kuasi eksperimen. Populasi dalam penelitian ini adalah seluruh siswa kelas V MI PUI Dermayu Sindang Indramayu dengan jumlah 119 siswa yang terbagi menjadi 3 kelas dengan mengambil sampel 2 kelas secara acak kelas dengan teknik simple random sampling. Instrumen untuk mengukur hasil belajar berupa tes dalam bentuk soal uraian. Teknik analisis datanya menggunakan uji statistik. Kesimpulan dari hasil penelitian bahwa (1) rata-rata hasil belajar siswa yang menggunakan media model padat lebih tinggi dibandingkan dengan hasil belajar siswa yang menggunakan media gambar; (2) terdapat perbedaan rata-rata hasil belajar matematika siswa pada materi geometri antara siswa yang pembelajarannya menggunakan media gambar dengan media model padat; (3) penggunaan media model padat pada pembelajaran matematika dengan materi geometri pada penelitian ini lebih baik dibandingkan dengan penggunaan media gambar.
\end{abstract}

Kata kunci: Geometri, Hasil Belajar Matematika, Media Gambar, Media Model Padat

\begin{abstract}
This study aims to analyze the average difference in students' mathematics learning outcomes on geometry material whose learning uses image media with solid model media. The research method used is quasi-experimental. The population in this study were all students of class V MI PUI Dermayu Sindang Indramayu with a total of 119 students who were divided into 3 classes by taking 2 classes randomly using a simple random sampling technique. The instrument for measuring learning outcomes is in the form of a test in the form of a description. The data analysis technique uses statistical tests. The conclusions from the results of the study are that (1) the average student learning outcomes using solid model media is higher than student learning outcomes using image media; (2) there is a difference in the average student learning outcomes in geometry material between students whose learning uses image media and model media on the subject; (3) the model of using solid media in mathematics
\end{abstract}


learning with geometry material in this study is better than the use of media images.

Keywords: Geometry, Mathematics Learning Outcomes, Image Media, Solid Model Media

\section{Pendahuluan}

Hasil belajar merupakan tujuan pengajaran yang diharapkan semua peserta didik. Untuk menunjang tercapainya tujuan pengajaran tersebut perlu adanya kegiatan belajar mengajar yang melibatkan siswa, guru, materi pelajaran, metode pengajaran, kurikulum dan media pembelajaran yang sesuai dengan kebutuhan siswa. Dalam kamus besar Bahasa Indonesia (2005:895) tertulis hasil belajar adalah penguasaan pengetahuan atau keterampilan yang dikembangkan oleh mata pelajaran, lazimnya ditunjukkan dalam nilai tes atau angka nilai yang diberikan guru. Menurut pendapat Sudjana (2005:22) hasil belajar terdiri dari 3 ranah yaitu: ranah kognitif, ranah afektif, dan ranah psikomotorik. Hasil belajar dari peserta didik penting untuk diketahui baik individual maupun kelompok sebab hasil belajar ini tidak hanya sebagai indikator keberhasilan, dan juga berguna bagi guru yang bersangkutan sebagai umpan balik dalam melaksanakan pembelajaran di kelas apakah akan diadakan perbaikan dalam proses belajar mengajar ataupun tidak. Hasil belajar ini merupakan hasil dari proses belajar yang berupa pengetahuan dan keterampilan yang dapat diukur dengan tes. Dimana hasil belajar setiap peserta didik akan berbeda satu sama lain artinya dengan materi yang sama, guru yang mengajar sama dan strategi yang ditetapkan juga sama tetapi belum tentu menghasilkan hasil belajar yang sama. Hal ini dipengaruhi oleh beberapa faktor dalam pencapaian hasil hasil belajar peserta didik, seperti yang disebutkan oleh Suryabrata yang dikutip Pratiwi (2015:85) yaitu : faktor internal dan eksternal. Faktor internal meliputi kecerdasan / intelegensi, jasmaniah / pancaindera, sikap, minat, bakat, dan motivasi belajar. Sedangkan faktor eksternalnya meliputi lingkungan keluarga, lingkungan sekolah, dan lingkungan masyarakat. Hasil belajar matematika adalah sebuah bentuk kemampuan yang ditunjukkan oleh anak didik dalam belajar matematika. Menurut Subarinah (2006: 1) menjelaskan, matematika adalah ilmu pengetahuan yang mempelajari struktur yang abstrak dan pola hubungan yang ada didalamnya. Hakikatnya belajar matematika adalah belajar konsep, struktur konsep, dan mencari hubungan antar konsep dan strukturnya.

Terdapat beberapa penelitian sebelumnya mengenai hasil belajar matematika siswa diantaranya menurut Zagir (2017), hasil belajar siswa pada mata pelajaran Matematika di 
Sekolah Dasar Negeri 04 Bati Tahun Pelajaran 2016/2017 kategori rendah. Faktor-faktor yang mempengaruhi rendahnya hasil belajar siswa pada mata pelajaran matematika tersebut meliputi faktor fasilitas sekolah, keluarga, psikologis, kemampuan siswa, interaksi siswa, media elektronik dan kedisplinan siswa. Menurut Arunti (2013), rendahnya hasil belajar matematika siswa kelas V di MIN Ponjong Gunung Kidul dipengaruhi oleh beberapa faktor diantaranya minat belajar, kesehatan, perhatian siswa, orangtua, alat dan metode. Sedangkan menurut Mustika (2018), faktor eksternal yang menyebabkan rendahnya hasil belajar matematika siswa kelas III di SD Negeri 1 Lambheu Aceh Besar pada pelajaran matematika terdiri atas faktor guru, orang tua dan teman serta kurang tepatnya penggunaan media oleh guru, kurangnya dukungan teman sebaya dan kurangnya perhatian yang didapatkan siswa dari orang tua.

Hal lain yang menyebabkan matematika dianggap sulit dan membosankan adalah penggunaan metode pembelajaran yang tidak efektif dan tidak efisien, seperti yang dikutip dari sebuah penelitian bahwa salah satu yang menyebabkan siswa mengalami kesulitan dalam geometri adalah pendekatan yang digunakan dalam pembelajaran matematika adalah menggunakan pendekatan konvensional. Pada pembelajaran ini guru memberikan definisi, sifat-sifat geometri dan memberikan contoh soal, siswa hanya pasif atau siswa tidak melakukan eksplorasi, membuktikan sifat-sifat, menyusun konjektur kemudian mengevalusinya dan tidak terjadi diskusi kelompok atau antar kelompok, guru yang aktif dalam pembelajaran, sedangkan siswa hanya menerima materi. Ini merupakan salah satu penyebab rendahnya kualitas pemahaman siswa terhadap matematika (Zulkardi, 2001)

Sebagai contoh dalam pembelajaran geometri yang merupakan salah satu cabang dari matematika yang menuntut berpikir abstraks masih menemukan kesulitan cara menyampaikan materi yang diajarkan kepada siswa. Oleh karena itu diperlukan suatu media atau alat peraga yang sesuai, hal ini senada dengan sebuah penelitian dalam sebuah artikel jurnal yang menyatakan bahwa siswa memerlukan suatu alat atau media yang mampu untuk memvisualisasikan materi yang sedang dipelajari. Agar proses pembelajaran lebih optimal, diperlukan sumber belajar juga media pembelajaran yang dapat memudahkan siswa dalam memahami konsep yang dipelajari (Widjayanti, dkk; 2019). Dimana media pembelajaran adalah alat bantu untuk menyampaikan pesan dan mempermudah dalam mempelajari sesuatu (Akbar, 2013). 
Dalam geometri dikenal dua media yang digunakan yaitu media gambar dan media model padat. Menurut Sundayana (2016), media gambar adalah segala sesuatu yang diwujudkan secara visual ke dalam bentuk dua dimesi sebagai curahan ataupun pikiran yang bentuknya bermacam-macam, seperti lukisan, potret, slide, film, strip, opaque projector. Sedangkan media model padat biasanya memperlihatkan bagian permukaan luar daripada objek dan membuang bagian-bagian yang membingungkan gagasan-gagasan utamanya dari bentuk, warna, dan susunannya. Menurut Ashar (2016) media model padat memiliki arti sebuah media yang tampilannya dapat diamati dari arah pandang mana saja dan mempunyai dimensi panjang, lebar dan tinggi/tebal, kebanyakan merupakan objek sesungguhnya (real object).

Penggunaan media atau alat peraga dimaksudkan untuk memberikan motivasi siswa dalam belajar yang dapat berimplikasi pada prestasinya. Sejalan dengan uraian di atas agar siswa dapat tahu, mengerti, dan mengingat lebih lama materi yang diberikan dalam mempelajari konsep geometi, tentunya tak lepas dari peranan guru dalam memilih model penyajian materi. Oleh karena itu penelitian ini bertujuan untuk mengetahui ada tidaknya perbedaan rata-rata hasil belajar matematika siswa pada materi geometri yang pembelajarannya menggunakan media gambar dengan media model padat.

\section{Metode}

Metode yang digunakan adalah kuasi eksperimen dengan desain berupa rancangan kelompok-kontrol (pretest dan postest). Desain penelitian ini digunakan karena dipilih kelompok-kontrol dengan dua perlakuan pembelajaran yang berbeda. Kelas yang pertama diberi perlakuan menggunakan media gambar (kelas kontrol) dan kelas kedua diberi perlakuan menggunakan media model padat (kelas eksperimen) pada materi geometri. Dimana untuk media gambar yang digunakan berupa gambar dua dimensi bangun datar dan bangun ruang, sedangkan media model padatnya berupa alat peraga bangun datar dan bangun ruang tiga dimensi yang terbuat dari bahan akrilik. Hal ini dilakukan untuk mengetahui apakah terdapat perbedaan rata-rata hasil belajar matematika siswa pada materi geometri yang menggunakan media gambar dengan media model padat. Untuk desain penelitiannya dapat digambarkan sebagai berikut : 


$$
\begin{aligned}
& R X_{1} \mathrm{O} \\
& R X_{2} \mathrm{O}
\end{aligned}
$$

Keterangan :

$$
\begin{array}{ll}
\mathrm{R} & \text { : Random } \\
\mathrm{O} & : \text { Tes Akhir } \\
\mathrm{X}_{1} & : \text { Perlakuan I (menggunakan media gambar dalam pembelajaran matematika } \\
& \text { pada materi geometri) } \\
\mathrm{X}_{2} & \text { : Perlakuan II (menggunakan media model padat dalam pembelajaran } \\
& \text { matematika pada materi geometri). }
\end{array}
$$

Variabel yang akan diukur dalam penelitian ini adalah rata-rata hasil belajar siswa maka instrumennya berbentuk tes prestasi yaitu soal-soal dalam bentuk uraian. Hal ini dimaksudkan untuk mengetahui pemahaman dan kemampuan siswa dalam menyelesaikan soal-soal tes dengan tahap-tahap penyelesaiannya. Dimana instrument tersebut diuji validitas dan reliabilitasnya terlebih dahulu. Pengujian validitasnya dengan menggunakan rumus product moment yang dikemukakan oleh Pearson. Dari hasil uji validitas tersebut diperoleh 5 item yang termasuk valid yaitu untuk soal nomor 1 kategori rendah; soal nomor 3,4, dan 5 kategori soal tinggi; dan soal nomor 2 kategori sangat tinggi. Sedangkan untuk hasil uji reliabilitasnya tersebut diperoleh koefisien reliabilitas sebesar 0,6204 dengan kategori Reliabel, berdasarkan kategori menurut Suherman (1990:177).

Penelitian dilakukan di MI PUI Sindang Kabupaten Indramayu. Populasi dalam penelitian ini adalah seluruh siswa kelas V sebanyak 119 siswa yang terbagi dalam 3 kelas. Mengingat populasi penelitian ini tersebar dalam 3 kelas dengan karakteristik tiap kelas relatif sama, maka sampel penelitiannya adalah 2 kelas yang diambil secara acak dan terpilih kelas V Al-arqom sebagai kelas kelompok I yang pembelajarannya menggunakan media gambar dan kelas V Ubaedah sebagai kelas kelompok II yang pembelajarannya menggunakan media model padat.

Teknik analisis datanya menggunakan teknik uji statistik yaitu (a) Untuk mengetahui gambaran siswa yang pembelajaranya menggunakan media gambar dan media model padat dengan cara menghitung skor/nilai terendah dan tertinggi, rentang nilai, median/rata-rata, simpangan baku atau deviasi standar dan diagram batang atau diagram garis; dan (b) Untuk menguji hipotesis atau menjawab rumusan masalah apakah terdapat perbedaan hasil belajar 
matematika siswa pada materi geometri yang pembelajarannya menggunakan media gambar dengan media model padat, yaitu dari data hasil tes akhir yang diberikan kepada kelompok eksperimen dan kelompok kontrol.

Adapun langkah-langkahnya antara lain: (1) Menyusun tabel distribusi frekuensi; (2) Menghitung rata-rata hasil post test dari sampel kelompok control dan kelompok eksperimen; (3) Menghitung deviasi standar (simpangan baku) dari masing-masing kelompok untuk mengetahui penyebaran kelompok data; (4) Melakukan uji normalitas dari distribusi masing-masing kelompok; (5) Jika keduanya berdistribusi normal dilanjutkan dengan pengetesan tentang homogenitas variansinya; (6) Jika salah satu atau kedua data hasil tes akhir kelompok control dan kelompok ekperimen tidak berdistribusi normal, maka akan dilakukan uji U Mann Whitney untuk menentukan perbedaan rata-rata dari kedua kelompok; (7) Jika salah satu atau kedua data hasil tes akhir kelompok control dan kelompok ekperimen berditribusi normal, maka akan dilanjutkan dengan Uji Homogenitas varians; (8) Jika distribusi data hasil tes akhir normal dan homogen, maka akan dilakukan uji t; dan (9) Jika kedua distribusi tersebut normal tetapi variansinya tidak homogen dilanjutkan dengan uji $t^{\prime}$.

Instrumen yang digunakan berupa tes akhir (post test) dalam bentuk soal uraian sebanyak 5 soal dengan imdikator penilaiannya antara lain (1) siswa dapat menjelaskan dengan kata-kata yang berkaitan dengan unsur-unsur bentuk bangun ruang, (2) Siswa dapat menentukan unsur-unsur bangun ruang, (2 dan 3) Siswa dapat menentukan volume kubus, balok, prisma, tabung, kerucut, limas dan bola, serta (5) Siswa dapat menggunakan rumus volume kubus, balok, prisma, tabung, kerucut, limas dan bola untuk menyelesaikan masalah sehari-hari. Nilai hasil post-test siswa kemudian dirata-ratakan baik dari kelas kelompok I dan II kemudian diolah yang bertujuan untuk mengetahui perbedaan rata-rata hasil belajar matematika siswa pada materi geometri yang menggunakan media gambar dengan media model padat.

\section{Hasil Penelitian Dan Pembahasan}

Hasil penelitian yaitu berupa data hasil tes akhir mengenai perbandingan rata-rata hasil belajar matematika siswa pada materi geometri antara yang menggunakan media 
gambar dengan media model padat di kelas V MI PUI Dermayu Sindang lndramayu pada tahun pelajaran 2009-2010, diperoleh hasil sebagai berikut:

Tabel 1. Hasil Pengelolaan Data Tes Akhir

\begin{tabular}{lcc}
\hline \multicolumn{1}{c}{ Nilai } & Kelas Eksperimen & Kelas Kontrol \\
\hline Jumlah siswa $(\mathrm{n})$ & 40 & 40 \\
\hline Rata-rata $\overline{(x)}$ & 67,70 & 52,70 \\
\hline Standar Deviasi (S) & 15,02 & 16,37 \\
\hline
\end{tabular}

Berdasarkan hasil tabel $1 \mathrm{di}$ atas terlihat bahwa hasil rata-rata kelompok kelas eksperimen lebih tinggi dibandingkan dengan kelas kontrol, artinya hasil belajar kelas eksperimen secara signifikan lebih baik dibandingkan kelas control. Hal ini diperkuat dengan nilai standar deviasi yang berbanding terbalik dengan hasil standar deviasi pada kelas eksperimen lebih kecil daripada kelas control, artinya kemungkinan sebaran data atau penyimpangan data dalam sampel pada kelas eksperimen relatif lebih kecil atau lebih sedikit daripada pada kelas control sehingga hasil dari rata-rata di atas menjadi lebih akurat. Langkah selanjutnya yaitu uji normalitas dan homogenitas dari kedua kelompok sampel. Setelah perhitungan rata-rata dan standar deviasi nilai tes akhir kedua kelompok sampel, maka dilanjutkan pengujian normalitas. Untuk menguji kenormalan digunakan uji chikuadrat untuk itu diperlukan $X_{\text {hitung }}^{2}$ dan $X_{\text {tabel }}^{2}$, kriteria yang digunakan dalam menguji kenormalan adalah $X_{\text {hitung }}^{2}<X_{\text {tabel }}^{2}$, maka data tersebut normal. Hasil dari uji normalitas terlihat pada tabel 2 berikut.

Tabel 2. Normalitas Distribusi Hasil Tes Akhir

\begin{tabular}{lcc}
\hline Kelompok & $\boldsymbol{X}_{\text {hitung }}^{\mathbf{2}}$ & $\boldsymbol{X}_{\text {tabel }}^{\mathbf{2}}$ \\
\hline Kelas Eksperimen & 2,44 & 7,81 \\
\hline Kelas Kontrol & 3,48 & 7,81 \\
\hline
\end{tabular}

Berdasarkan tabel 2 di atas dari hasil perhitungan dengan menggunakan statistik uji $\mathrm{x}^{2}$ (chi kuadrat), diketahui bahwa data hasil tes akhir kelas eksperimen dan kelas kontrol menyebar normal karena $X_{\text {hitung }}^{2}<X_{\text {tabel }}^{2}$, dengan $X_{\text {hitung }}^{2}=2,44$ (untuk kelas eksperimen) dan $X_{\text {hitung }}^{2}=3,48$ (untuk kelas kontrol), adapun $X_{\text {tabel }}^{2}=7,81$ dengan taraf kepercayaan 95\%, serta $d k=k-3=6-3=3$. 
Sedangkan untuk pengujian homogenitas dua varians dilakukan dengan uji statistik F. Kriteria yang digunakan dalam pengujian homogenitas adalah varians kedua kelompok homogen, jika Fhitung $<\mathrm{F}_{\text {tabel }}$ terpenuhi. Untuk hasil perhitungan homogenitas terlihat pada tabel 3 .

Tabel 3. Perhitungan Uji Homogenitas Varians (F)

\begin{tabular}{|c|c|c|c|}
\hline Kelompok & $\mathrm{n}$ & Fhitung & $\mathrm{F}_{\text {tabel }}$ \\
\hline Kelas Eksperimen & 40 & \multirow{2}{*}{1,10} & \multirow{2}{*}{1,73} \\
\hline Kelas Kontrol & 40 & & \\
\hline
\end{tabular}

Berdasarkan tabel 3 di atas dan hasil pengolahan data tes akhir, diperoleh Fhitung $=1,10$ dan $\mathrm{F}_{\text {tabel }}=1,73$ (dengan taraf kepercayaan 95\%) artinya varians data hasil tes akhir kelas eksperimen dan kelas kontrol bersifat homogen, karena Fhitung $<\mathrm{F}_{\text {tabel. }}$

Berdasarkan perhitungan uji normalitas $x^{2}$ data hasil tes akhir (tabel 2) dan perhitungan uji homogenitas dua varians atau F (tabel 3) , temyata hasil tes akhir kedua kelompok sampel berdistribusi normal dan homogen. Maka selanjutnya adalah menghitung perbedaan dua rata-rata dengan menggunaka uji-t. Berikut hasil perhitungan ditunjukkan pada tabel 4 .

Tabel 4. Perbedaan Dua Rata-rata

\begin{tabular}{|c|c|c|c|c|c|}
\hline Kelompok & $\overline{(x)}$ & $S^{2}$ & Sg & thitung & $t_{\text {tabel }}$ \\
\hline Kelas Eksperimen & 67,70 & 247,94 & \multirow{2}{*}{16,14} & \multirow{2}{*}{4,22} & \multirow{2}{*}{1,667} \\
\hline Kelas Kontrol & 52,70 & 272,97 & & & \\
\hline
\end{tabular}

Berdasarkan tabel 4 di atas, hasil perbedaan dua rata-rata dan hasil perhitungan data tes akhir diperoleh nilai thitung $=4,22$ dan tabel $=1,667$ (dengan taraf kepercayaan 95\%) serta nilai rata-rata hasil tes akhir kelas eksperimen lebih tinggi dari nilai rata-rata hasil tes akhir kelas kontrol artinya terdapat perbedaan nilai rata-rata antara kelas eksperimen dengan kelas kontrol karena thitung $>$ tabel. Berdasarkan hasil perhitungan, thitung $<$ tabel tidak terpenuhi, dengan demikian Ho ditolak dan Ha diterima sehingga dapat disimpulkan bahwa terdapat perbedaan rata-rata hasil belajar matematika yang signifikan pada materi geometri antara yang menggunakan media gambar dengan media model padat. 
Berdasarkan hasil analisis data yang telah diuraikan di atas, maka hasil penelitian terdapat perbedaan hasil belajar matematika siswa pada materi geometri antara siswa yang pembelajarannya menggunakan media gambar dengan menggunakan media model padat.

Dengan menggunakan media model padat kegiatan pembelajaran matematika pada materi geometri dapat menjadi salah satu strategi guru untuk membuat suasana yang menyenangkan dan tidak menjenuhkan bagi siswa dalam mempelajari konsep-konsep geometri. Sejalan dengan hal itu (Asep Robiana, 2020) juga mengemukakan bahwa banyak media pembelajaran yang bisa digunakan untuk menciptakan suasana pembelajaran yang menyenangkan, nyaman, dan membuat siswa bahagia sehingga tujuan pembelajaran bisa tercapai dan kemampuan matematis siswa meningkat.

Selain seorang guru dapat menerangkan matematika dengan mudah siswa pun dapat menerima pelajaran yang diberikan dengan nyata, tidak berangan-angan dan dapat memberi semangat belajar kepada siswa. Sehingga dalam kondisi seperti itu siswa dapat menerima pelajaran matematika dengan baik, sekaligus menghapus kesan bahwa matematika merupakan pelajaran yang membingungkan, memusingkan dan gurunya selalu serius. Hal tersebut sejalan dengan penelitian yang dilakukan (Kabita Camelia, 2018) mengemukakan bahwa salah satu faktor yang dapat menentukan pencapaian hasil belajar adalah siswa untuk aktif dan bertanggung jawab dalam pembelajaran maka disarankan bagi siswa untuk terlibat aktif dalam proses pembelajaran.

Berdasarkan hasil penelitian yang penulis lakukan di MI PUI Dermayu Sindang Indramayu terhadap 40 siswa kelas $\mathrm{V}$ yang dijadikan sebagai kelas eksperimen, dapat diketahui bahwa siswa yang pembelajarannya menggunakan media model padat siswa lebih mudah untuk memahami materi. Dari hasil pengolahan data tes akhir diperoleh nilai ratarata 67,70 . Sedangkan berdasarkan hasil penelitian terhadap 40 siswa yang dijadikan sebagai kelas kontrol, dapat diketahui bahwa siswa yang pembelajarannya menggunakan media gambar siswa mengalami kesulitan dalam memahami materi misalnya dalam menyebutkan unsur-unsur bangun ruang, siswa mengalami kesulitan jika tidak dihadapkan langsung dengan bendanya. Hasil pengolahan data tes akhir diperoleh nilai rata-rata 51,70.

Uji t dikenal dengan uji parsial, yaitu untuk menguji bagaimana pengaruh masingmasing variabel bebasnya secara sendiri-sendiri terhadap variabel terikatnya. Hasil dari perhitungan uji beda rata-rata (uji-t) diperoleh thitung $=4,22$ dan $t_{\text {tabel }}=1,667$. karena thitung $>$ 
ttabel maka tolak Ho atau terima Ha. Jadi berdasarkan hasil perhitungan terdapat perbedaan hasil belajarmatematika pada materi geometri antara yang menggunakan media gambar dengan media model padat. Dengan demikian, dalam penelitian ini hasil belajar matematika siswa yang pembelajarannya menggunakan media model padat lebih tinggi dari hasil belajar matematika siswa yang pembelajarannya menggunakan media gambar.

Hal ini sejalan dengan beberapa penelitian yang terkait dengan pembahasan dalam penggunaan media pembelajaran terhadap hasil belajar siswa, yaitu: penggunaan media belajar yang refresentatif telah meningkatkan minat belajar siswa yang berdampak pada hasil belajar matematika (Tatan, 2012), manfaat media dalam proses pembelajaran adalah memperlancar interaksi antara guru dengan siswa sehingga pembelajaran akan lebih efektif dan efisien (Samura, 2015), hasil pembelajaran dengan menggunakan media pembelajaran memberikan pengaruh tinggi terhadap hasil belajar siswa pada pembelajaran memecahkan masalah matematika (Tehayanti, 2015), dan hasil pelajaran matematika siswa yang memiliki minat belajar tinggi dan diajar dengan media tiga dimensi lebih tinggi dari pada dengan media dua dimensi (Sugiyati, 2016).

Dalam artikel penelitian yang lain menyebutkan bahwa: secara signifikan terdapat pengaruh interaksi media pembelajaran terhadap hasil belajar matematika (Firdaus, 2017), media pembelajaran berpengaruh signifikan terhadap hasil belajar peserta didik (Ismawati, 2017), terdapat pengaruh positif yang signifikan melalui melalui hasil analisis data yang menyatakan bahwa kelompok eksperimen (yang diberikan perlakuan dengan media pembelajaran) memberikan pengaruh positif lebih baik daripada kelompok kontrol/konvensional (Lastrijanah \& Mawardani, 2017), pembelajaran akselerasi yang menggunakan media lebih baik daripada siswa yang menggunakan pembelajaran konvensional (Yaniawati, R..Poppy., dkk, 2017), terdapat peningkatan hasil dari pre-test dengan posttest dengan penggunaan model pembelajaran DDFC berbantuan software GeoGebra dibandingkan dengan model pembelajaran konensional (Kariadinata., dkk, 2017), serta media merupakan suatu alat atau sarana sebagai perantara untuk menyampaikan bahan pelajaran dari guru kepada anak didik dimana manfaat dari media dalam pembelajaran yaitu: (1) Penyampaian materi pelajaran dapat diseragamkan; (2) Proses pembelajaran menjadi lebih jelas dan menarik; (3) Proses pembelajaran menjadi lebih interaktif; (4) Efisiensi dalam waktu dan tenaga; (5) Meningkatkan kualitas hasil belajar 
siswa; (6) Media memungkinkan proses belajar dapat dilakukan dimana saja dan kapan saja (Karo-Karo \& Rohani, 2018).

Beberapa penelitian yang masih terkait dengan pembahasan ini yaitu: terdapat interaksi yang sangat signifikan antara media pembelajaran dan gaya belajar dalam mempengaruhi hasil belajar (Nurwidayanti \& Mukminan, 2018), hasil belajar matematika siswa yang memeperoleh pembelajaran langsung berbantuan media lebih baik dari siswa yang memperoleh pembelajaran langsung (Pratama. dkk, 2019), penggunaan media pembelajaran yang tepat dalam proses belajar mengajar dapat meningkatkan secara signifikan hasil belajarmatematika siswa sesuai dengan tujuan pembelajaran di kelas (Nurhayati dkk, 2020), dan dengan pemilihan media pembelajaran yang baik dan tepat dapat meningkatkan hasil belajar mahasiswa (Suryani, 2020).

\section{Kesimpulan dan Saran}

Berdasarkan hasil penelitian yang dilakukan di MI PUI Dermayu Sindang Indramayu terhadap 40 siswa yang dijadikan kelas eksperimen dan 40 siswa sebagai kelas kontrol, terlihat bahwa Siswa yang pembelajarannya menggunakan media model padat terlihat lebih bersemangat dan aktif dalam belajar. Jadi dengan demikian dapat dapat disimpulkan bahwa: (1) hasil belajar siswa yang menggunakan media model padat lebih tinggi dibandingkan dengan hasil belajar siswa yang menggunakan media gambar; (2) terdapat perbedaan hasil belajar matematika siswa pada materi geometri antara siswa yang pembelajarannya menggunakan media gambar dengan media model padat; (3) penggunaan media model padat pada pembelajaran matematika dengan materi geometri pada penelitian ini lebih baik dibandingkan dengan penggunaan media gambar.

Adapun saran yang dapat diberikan terkait dengan penelitian ini adalah dengan menggunakan media model padat, kegiatan pembelajaran matematika pada materi geometri dapat menjadi salah satu alternative atau strategi guru untuk membuat suasana yang menyenangkan dan tidak menjenuhkan bagi siswa dalam mempelajari konsep-konsep geometri agar lebih mudah dipahami oleh siswa. 


\section{Referensi}

Arunti, Rindang. 2013. Faktor-Faktor Yang Mempengaruhi Rendahnya Hasil belajarMatematika Pada Siswa Kelas V Madrasah Ibtidaiyah Negeri Ponjong Gunungkidul Tahun ajaran 2012/2013. [Online]. Tersedia: https://digilib.uinsuka.ac.id/id/eprint/9206/1/BAB\%20I\%2C\%20V\%2C\%20DAFTAR\%20PUSTAKA.pdf. [1 Juli 2021]

Firdaus, Indra Cahya. 2017. Jurnal Pengaruh Penggunaan Media Pembelajaran dan Konsep Diri Siswa Terhadap Haisl Belajar Matematika Siswa. [Online]. Tersedia: http://openjournal.unpam.ac.id/index.php/informatika/article/view/1505/pdf. [8 Juli 2021].

Ismawati, Lilik. 2017. Pengaruh Media Pembelajaran dan Motivasi Berprestasi Terhadap Hasil Belajar Peserta Didik MAN Di Kabupaten Gresik. [Online]. Tersedia: https://journal.unesa.ac.id/index.php/jpeka/article/view/1948/1331. [10 Juli 2021].

Kariadinata, R., dkk. 2017. The implementation of GeoGebra software-assited DDFC instructional model for improving students' Van-Hiele geometry thinking skill. [Online]. Tersedia: https://dl.acm.org/doi/abs/10.1145/3124116.3124129?casa token=74beBKfy3SQAAAA A:JTKky3Ka5htwrtBpC-SdNc obBgq12NNiMqNCVdXHn7 Iv AIGBQgcnyAuhWuL3j-ldVbMPvG9Ajek. [15 Juli 2021].

Karo-karo, Isran Rasyid Karo-Karo, Rohani. 2018. Manfaat Media Dalam Pembelajaran. [Online]. Tersedia: http://jurnal.uinsu.ac.id/index.php/axiom/article/view/1778/1411. [8 Juli 2021].

Lastrijanah., Prasetyo, T., \& Mawardani, A. 2017. Penggunaan Media Pembelajaran Geoboard Terhadap Hasil Belajar Siswa. [Online]. Tersedia: https://ojs.unida.ac.id/index.php/jtdik/article/view/895, [8 Juli 2021].

Mustika, Sara. 2018. Penyebab Rendahnya Hasil Belajar Matematika Siswa Kelas III di SD Negeri 1 Lambheu Aceh Besar. [Online]. Tersedia: http://www.jim.unsyiah.ac.id/pgsd/article/view/8668/3703. [5 Juli 2021]

Nurhayati., Arafat, Yasir., \& Fitriani, Yessi. 2020. Penggunaan Media Power Point Dalam Pembelajaran Matematika dan Pengaruhnya Terhadap Prestasi Belajar Siswa. [Online]. Tersedia:http://journal.binadarma.ac.id/index.php/jurnalbinaedukasi/article/downloa d/1036/580, [8 Juli 2021].

Nurwidayanti, Dewi, Mukminan. 2018. Pengaruh Media Pembelajaran Terhadap Hasil Belajar Ekonomi Ditinjau dari Gaya Belajar Siswa SMA Negeri. [Online]. Tersedia: https://journal.uny.ac.id/index.php/hsjpi/article/view/17743/12824. [10 Juli 2021] 
Pratama, Ryan Angga., Ananta, Rudi., \& Yuniarti, Suci. 2019. Pengaruh Media Pembelajaran Monopoli Matematika (Monotika) Terhadap Hasil Belajar Matematika Siswa. [Online]. Tersedia:

https://journal.stkip-andimatappa.ac.id/index.php/histogram/article/view/291, [8 Juli 2021]

Pratiwi, Noor Komari. 2015. Pengaruh Tingkat Pendidikan, Perhatian Orang Tua, dan Minat Belajar Siswa Terhadap Hasil belajarBahasa Indonesia Siswa SMK Kesehatan Di Kota Tangerang. Jurnal Pujangga Volume 1, Nomor 2, Desember. [Online]. Tersedia: http://journal.unas.ac.id/pujangga/article/view/320. [5 Juli 2021]

Robiana, Asep; Hendri Handoko. 2020. Pengaruh Penerapan Media UnoMath untuk Meningkatkan Kemampuan Komunikasi Matematis dan Kemandirian Belajar Siswa. IAIN Syekh Nurjati Cirebon. [Online]. Tersedia: https://journal.institutpendidikan.ac.id/index.php/mosharafa/article/view/mv9n3 15/ 641. [8 Juli 2021]

Rostina Sundayana, Media dan Alat Peraga dalam Pembelajaran Matematika (Bandung: Alfabeta, 2016)

Samura, Asri Ode. 2015. Penggunaan Media dalam Pembelajaran Matematika dan Manfaatnya. [Online].

Tersedia: https://ejournal.unkhair.ac.id/index.php/deltapi/article/view/145/108. [8 Juli 2021].

Sari, Siska Puspita; Madio, Sukanto Sukandar. 2013. Pengaruh Penerapan Model Pembelajaran Kooperatipe Tipe Think Pair Share (Tps) Terhadap Hasil Belajar Matematika Siswa Smp. [Online].

Tersedia: https://journal.institutpendidikan.ac.id/index.php/mosharafa/article/view/mv2n1 4/1 97. [5 Juli 2021].

Sugiyati. 2016. Pengaruh Media Pembelajaran dan Minat Belajar terhadap Hasil Belajar Matematika. [Online]. Tersedia: https://journal.uhamka.ac.id/index.php/jppp/article/view/1259/481. [5 Juli 2021].

Suryani, Lely. 2020. Pengaruh Media Pembelajaran Terhadap Hasil Belajar Geometri Ruang pada Mahasiswa Program Studi Pendidikan Matematika. [Online]. Tersedia: https://ejournal.uniflor.ac.id/index.php/jupika/article/view/672/663. [8 Juli 2021].

Tatan Z.M. 2012. Pengaruh Penggunaan Media Belajar dan Minat Belajar terhadap Hasil Belajar Matematika. [Online]. Tersedia: https://core.ac.uk/download/pdf/236195944.pdf. [5 Juli 2021].

Tehayanti. 2015. Pengaruh Penggunaan Media Realita Terhadap Hasil belajar Matematika Siswa Kelas III.

[Online]. Tersedia: https://jurnal.untan.ac.id/index.php/jpdpb/article/download/9956/9734, [8 Juli 2021]. 
Widjayanti, Wegita Reski. 2019. Media Pembelajaran Interaktif Berbasis Animasi Pada Materi Statistika Untuk Siswa Kelas 7 SMP. [Online]. Tersedia: https://ejournal.unsri.ac.id/index.php/jpm/article/view/6294/pdf. [10 Juli 2021].

Yaniawati, R. P., dkk. 2017. Accelerated learning method using edmodo to increase students' mathematical connection and self-regulated learning. [Online]. Tersedia: https://dl.acm.org/doi/abs/10.1145/3124116.3124128?casa token=baYAArVWuYEAAA AA\%3Ab05Yjq_Jp7JjjdVSAKjpzGa3SjtP6yHumiyzxUBLxJ7d Zb0N1P2AEpVFG_xCF rx8E6DFpXcumyEmQI. [15 Juli 2021].

Zulkardi. (2001). Proses Belajar Mengajar. Jakarta: Bumi Aksara.

Zul Zagir. 2017. Analisis Faktor-Faktor Yang Mempengaruhi Rendahnya Hasil belajarSiswa Pada Mata Pelajaran Matematika di SD Negeri 04 BATI Tahun Pelajaran 2016/2017. STKIP Persada Khatulistiwa Sintang. [Online]. Tersedia: https://www.neliti.com/id/publications/271596/analisis-faktor-faktor-yangmempengaruhi-rendahnya-prestasi-belajar-siswa-pada-m. [10 Juli 2021] 